Original Research Paper

\title{
Prevalence of Escherichia Coli in Some Selected Foods and Children Stools with Special Reference to Molecular Characterization of Enterohemorrhagic Strain
}

\author{
${ }^{1}$ Farhan, R., ${ }^{2}$ S. Abdalla, ${ }^{3}$ H.A. Abdelrahaman, ${ }^{2}$ N. Fahmy and ${ }^{3}$ E. Salama \\ ${ }^{1}$ Biotechnology Research Center, Suez Canal University, Egypt \\ ${ }^{2}$ Department of Microbiology and Immunology, Faculty of Pharmacy, Suez Canal University, Egypt \\ ${ }^{3}$ Department of Food Hygiene, Faculty of Veterinary Medicine, Suez Canal University, Egypt
}

Article history

Received: 18-08-2014

Revised: 20-08-2014

Accepted: 4-11-2014

Corresponding Author: Farhan, R.

Biotechnology Research

Center, Suez Canal University,

Egypt

Email: salamaa_79@hotmail.com

\begin{abstract}
Escherichia coli is one of the most important etiologic agents of childhood diarrhea that represents a major public health problem in developing countries and now is being recognized as emerging enteropathogens in the well developed countries. Among the Diarrhegenic Escherichia Coli (DEC) this work was focused on the Enterohemorrhagic Escherichia Coli (EHEC) that produce Shigatoxins (Stxs). The infection is mainly transmitted through food of bovine origin such as beef and dairy products that has been often associated with outbreaks which ranged from mild diarrhea to the life-threatening hemolytic uremic syndrome. The aim of this study was to evaluate the incidence of potentially virulent STEC isolates from minced meat, some selected dairy products and from children clinical cases. Out of 360 samples, a total of 115 E.coli isolates were recovered as following $35(30.43 \%)$ isolate from meat, 21 (18.26\%) from raw milk, $31(26.96 \%)$ from cheese and 28 (24.35\%) from children stool. The identification were based on Microscopical examination, Biochemical identification and Serotyping. Twenty eight isolates were identified serologically. O26:K60 serotype $6(21.4 \%)$ was found to be the most prevalent serotype. Screening for virulence genes $\left(S t x_{1}, S t x_{2}\right.$, eaeA, hlyA) was done using multiplex PCR, which revealed detection of the target genes in 10 out of $115(8.7 \%)$ examined samples. About $7(70 \%)$ samples possessed eaeA gene alone; while $2(20 \%)$ samples contained $S t x_{2}$ gene. Both $S t x_{1}$ and eaeA genes were detected in 1(10\%) sample only.
\end{abstract}

Keywords: DEC, EHEC, Shigatoxins (Stxs), Childhood Diarrhea

\section{Introduction}

Escherichia coli is the predominant nonpathogenic facultative flora of the human intestine (Nataro and Kaper, 1998). Some E. coli strains, however, are the most important etiologic agent of childhood diarrhea and represent a major public health problem in developing countries (Toma et al., 2003). Among the E. coli causing intestinal diseases, there are six well-described pathotypes: Enteropathogenic E. coli (EPEC), enterotoxigenic E. coli (ETEC), Enteroinvasive E. coli (EIEC), Enterohaemorrhagic E. coli (EHEC), Enteroaggregative E. coli (EAEC) and diffusely adherent E. coli (DAEC) (Stenutz et al., 2006).

The infection is mainly food-borne, but it can also be acquired by person-to-person spread or direct contact with animals. Ruminants and in particular cattle, are considered to be the principal reservoir of $E$. coli, so food of bovine origin such as beef and dairy products has often been associated with outbreaks (Perelle et al., 2007). Moreover, an increasing number of episodes have been associated with consumption of fruits and vegetables fertilized with ruminants' manure or contaminated during harvesting or processing (Conedera et al., 2007).

Among the six recognized diarrhegenic categories of E. coli, ETEC is the most common, particularly in the developing countries (Qadri et al., 2005). EHEC is the most important recently emerged group of food-borne pathogens. It can cause severe gastrointestinal disease, including fatal infections and is being detected more frequently worldwide. EHEC strains not only produce 
potent cytotoxins (verotoxins) but have also acquired the ability to adhere to the intestinal mucosa in an intimate fashion (Fagan et al., 1999). Specific virulence factors such as enterotoxins and colonization factors differentiate ETEC from other categories of diarrheagenic E. coli (Qadri et al., 2005). Many assays for the detection of diarrheagenic E. coli are available, such as biochemical reactions, serotyping, phenotypic assays based on virulence characteristics and molecular detection methods (Nataro and Kaper, 1998; Nguyen et al., 2005). Among these, Polymerase Chain Reaction (PCR) is one of the molecular biology-based detection methods, is a commonly used method that gives rapid, reliable results and that also has a high sensitivity and a high specificity (Nguyen et al., 2005).

Recently various multiplex PCR methods have been developed for the simultaneous detection of several pathogenic genes in one PCR reaction. These methods showed high sensitivity and specificity for identification of human diarreheagenic E. coli (Arif and Salih, 2010).

The aim of this study was to evaluate the prevalence of E. coli in collected food of animal origin such as minced meat, raw milk, kareesh cheese and in fecal samples of clinical cases of children and to investigate the characteristics and efficacy of multiplex PCR to simultaneously detect diarrheagenic E. coli.

\section{Materials and Methods}

\section{Collection and Sampling Process}

Three hundred samples of minced meat, fresh raw milk and Kareesh cheese (one hundred of each) are randomly collected from butcheries, supermarkets, dairy stores and milk vendors. In addition, 60 random diarrheal stool samples were collected from different hospitals and private laboratories of children clinical cases. All samples were collected from different localities in Ismailia Governorate; the samples were transported to the laboratory without delay in a temperature-regulated ice box to be examined.

\section{Enrichment and Recovery of E.coli (ISO} 16654:2001; De Boer and Heuvelink, 2000)

About 25 g. or $\mathrm{mL}$ of examined samples were added to $225 \mathrm{~mL}$ of modified Tryptone Soya Broth ([Difco) supplemented with novobiocin solution $\left(20 \mathrm{mg} \mathrm{L}^{-1}\right)$. The samples were placed in individual bags homogenized in a stomacher for $2 \mathrm{~min}$ and incubated for $24 \mathrm{~h}$ at $37^{\circ} \mathrm{C}$. Each recovered sample was streaked onto modified Sorbitol MacConkey agar and incubated at $37^{\circ} \mathrm{C}$ for 24 h. Both of Cexifime and potassium tellurite were added to the SMAC to increase selectivity especially for heavily contaminated samples.
In parallel, a loopful from the incubated broth was streaked into Eosin Methylene Blue Agar. The inoculated plates were incubated at $37^{\circ} \mathrm{C}$ for $24 \mathrm{hr}$. Typical colonies of E. coli appear greenish, metallic and with dark purple center. Suspected colonies were purified and sub-cultured onto nutrient agar slopes and incubated at $37^{\circ} \mathrm{C}$ for $24 \mathrm{hr}$, then stored until further investigation was carried out.

\section{Confirmation of the Isolates}

Were carried out according to Edwards and Ewing's Identification of Enterobacteriaceae (Farmer et al., 1985).

\section{Serotyping}

The confirmed E. coli isolated strains were serological identified by Central Laboratories of Ministry of Health-Bacteriology Department-Cairo.

\section{Antimicrobial Susceptibility Testing (CLSI, 2011)}

All identified serotypes were tested for determination of their antimicrobial profiles. Susceptibility to antimicrobial agents was determined by the standardized disk diffusion assay on Mueller-Hinton agar (Difco, USA) with 8 different commercial antimicrobial susceptibility disks (Bioanalyse, Turkey) according to the recommendations of the Clinical and Laboratory Standards Institute (CLSI, 2011) guidelines. The antimicrobial tested and their corresponding disk concentrations were as follows: Erythromycin $(15 \mu \mathrm{g})$; Cefatriaxone $(30 \mu \mathrm{g})$; Chloramphenicol $(30 \mu \mathrm{g})$; Trimethoprim/Sulphamethoxazole(1.25-23.75 $\mu \mathrm{g})$; Ciprofloxacin $(5 \mu \mathrm{g})$; Azithromycin $(15 \mu \mathrm{g})$; Amikacin $(30 \mu \mathrm{g})$; Streptomycin $(10 \mu \mathrm{g})$. Isolates resistant to 3 or more different classes of antimicrobial agent were defined as multi-drug resistant.

\section{DNA Extraction}

DNAs were extracted from reference strain that obtained from the Central Laboratories of the Ministry of Health Bacteriology Department- Cairo and isolated strains by the method described by (Yokoyama, 1993; Toma et al., 2003). The reference and isolated strains were cultured in $2 \mathrm{~mL}$ of Luria-Bertani broth $(1 \%$ tryptone, $0.5 \%$ yeast extract, $0.5 \% \mathrm{NaCl}$ ) and incubated overnight at $37^{\circ} \mathrm{C}$ with shaking. Thirty-six microliters of broth culture was added to $4 \mu \mathrm{L}$ of $10 \mathrm{x}$ Tris-EDTA buffer (100 mM Tris-HCl, $10 \mathrm{mM}$ EDTA, pH 8.3) and $60 \mu \mathrm{L}$ of $2 \mathrm{x}$ proteinase $\mathrm{K}$ buffer $(100 \mathrm{mM} \mathrm{KCl}, 20 \mathrm{mM}$ Tris- $\mathrm{HCl}, 5 \mathrm{mM} \mathrm{MgCl} 2,1 \%$ Tween $20,800 \mu \mathrm{g}$ of proteinase $\mathrm{K} / \mathrm{mL}, \mathrm{pH} \mathrm{8.3)}$. After incubation for $90 \mathrm{~min}$ at $56^{\circ} \mathrm{C}$ and $10 \mathrm{~min}$ at $95^{\circ} \mathrm{C}$, the sample was centrifuged at $10,000 \times \mathrm{g}$ for $1 \mathrm{~min}$ and the supernatant was used as DNA template (Fig. 1). The DNA quantity and purity were assessed spectrophotometrically at 260-280 nm, which was determined with NanoDrop ND-1000 full spectrum UV-Vis spectrophotometer (USA). 


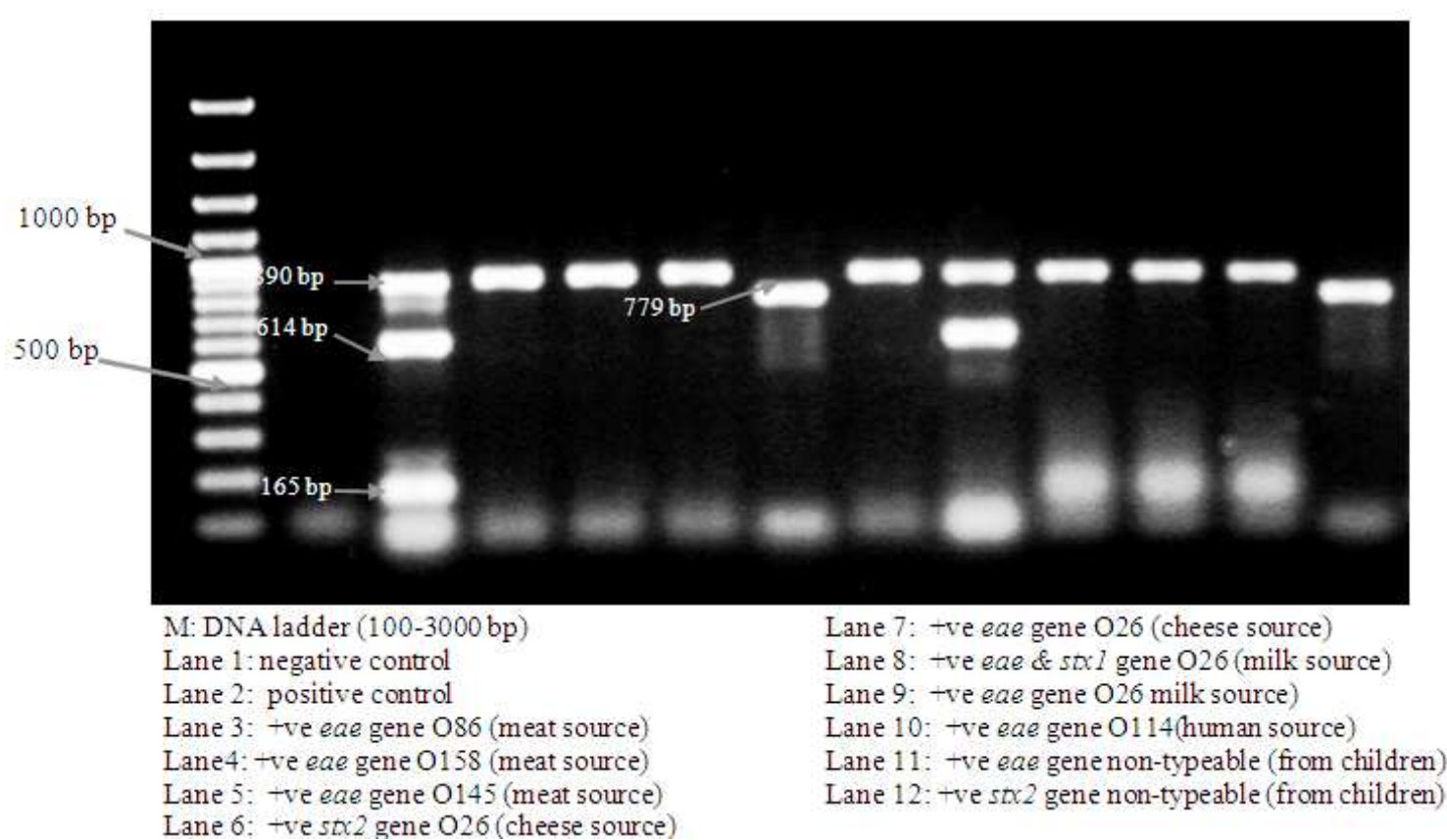

Fig. 1. DNA ladder

Table 1. Incidence of isolated E. coli from examined samples

\begin{tabular}{llllll}
\hline $\begin{array}{l}\text { Sample type } \\
\text { Isolates }\end{array}$ & $\begin{array}{l}\text { Minced meat } \\
(\mathrm{n}=100)\end{array}$ & $\begin{array}{l}\text { Raw milk } \\
(\mathrm{n}=100)\end{array}$ & $\begin{array}{l}\text { Kareesh cheese } \\
(\mathrm{n}=60)\end{array}$ & $\begin{array}{l}\text { Children stools } \\
(\mathrm{n}=100)\end{array}$ & $\mathrm{N}=360$ \\
\hline & $35(30.43 \%)$ & $21(18.26 \%)$ & $31(26.96 \%)$ & $28(24.35 \%)$ & $115(31.94 \%)$ \\
\hline
\end{tabular}

\section{Molecular Characterization (Fagan et al., 1999)}

Multiplex PCR for detection of $S t x_{1}, S t x_{2}$, eaeA and EHEC hlyA gene sequences was performed with an eppendorf MasterCycler Gradient (Eppendorf-NethelerHamburg, Germany). Oligonucleotide primers were manufactured commercially (Metabion International AG, Germany). Primers and the predicted lengths of PCR amplification products are listed in Table 1.

PCR assays were carried out in a $50 \mu \mathrm{L}$ volume containing $2 \mu \mathrm{L}$ of nucleic acid template prepared from isolated cultures (approximately $60 \mathrm{ng}$ of DNA) or $1 \mu \mathrm{L}$ (approximately $30 \mathrm{ng}$ ) of nucleic acid template prepared by using reference $E$. coli $\mathrm{O} 157: \mathrm{H} 7$ isolate which obtained from the Central Laboratories of the Ministry of Health Bacteriology Department- Cairo, $25 \mu \mathrm{L}$ of Master Mix (Fermentas, USA). Temperature conditions consisted of an initial $95^{\circ} \mathrm{C}$ denaturation step for $3 \mathrm{~min}$ followed by 35 cycles of $95^{\circ} \mathrm{C}$ for $20 \mathrm{~s}, 58^{\circ} \mathrm{C}$ for $40 \mathrm{~s}$ and $72^{\circ} \mathrm{C}$ for $90 \mathrm{~s}$. The final cycle was followed by $72^{\circ} \mathrm{C}$ incubation for 5 min (Fagan et al., 1999).

Ten microliters of PCR products were then electrophoresed on a $2 \%$ Agarose gel (Bioshop, Canada), stained with ethidium bromide (Sigma, USA) and visualized by UV transillumination. The buffer in the electrophoresis chamber and in the agarose gel was $1 \mathrm{X}$
TAE buffer. The amplicon was imaged with a gel documentation system LTF (Labortechnik, Germany).

\section{Results}

Percentage of isolated E. coli strains: A total of 115 E. coli strains were isolated regarding to the culture media and were confirmed by biochemical tests. About $35(30.43 \%)$ strains were isolated from minced meat, 21 (18.26\%); raw milk, 31 (26.96\%); Kareesh cheese samples and $28(24.35 \%)$ from the stool samples.

\section{Serotypes Detection}

Serogrouping was performed for all isolated E. coli strains. Only $28(24.35 \%)$ strains were serologically identified, while 87 strains (75.65\%) were non-typeable. Among the serological identified strains, EHEC were the most common type [8 isolates $(6.95 \%)]$.

Table 2 the results of serotyping.

\section{Antimicrobial Susceptibility Testing}

All Identified serotypes were susceptible to different 8 antimicrobial agents. The results obtained in this study for each tested antimicrobial agent, have been reported according to (CLSI, 2011). The strains were classified as Sensitive (s), Intermediate (I) or Resistant (R) based on the inhibition zone diameter. 
Table 2. Results of Serological identification of E. coli isolates from the examined samples

\begin{tabular}{|c|c|c|c|c|c|c|}
\hline \multicolumn{2}{|l|}{ Samples } & No of isolates & \multicolumn{2}{|c|}{ O-typable } & \multicolumn{2}{|c|}{ O-untypable (OUT) } \\
\hline \multicolumn{2}{|c|}{ Raw minced meat } & 35 & \multicolumn{2}{|c|}{$9(25.71 \%)$} & \multicolumn{2}{|c|}{$26(74.29 \%)$} \\
\hline \multicolumn{2}{|c|}{ Raw fresh milk } & 21 & \multicolumn{2}{|c|}{$5(23.80 \%)$} & \multicolumn{2}{|c|}{$16(76.19 \%)$} \\
\hline \multicolumn{2}{|c|}{ Kareesh cheese } & 31 & \multicolumn{2}{|c|}{$9(29.03 \%)$} & \multicolumn{2}{|c|}{$22(70.97 \%)$} \\
\hline \multicolumn{2}{|c|}{ Stool samples } & 28 & \multicolumn{2}{|c|}{$5(23.80 \%)$} & \multicolumn{2}{|c|}{$23(82.14 \%)$} \\
\hline Total & & 115 & \multicolumn{2}{|c|}{$28(24.34 \%)$} & \multicolumn{2}{|c|}{$87(75.65 \%)$} \\
\hline \multicolumn{2}{|l|}{$\begin{array}{l}\text { Strain } \\
\text { Character }\end{array}$} & $\begin{array}{l}\text { Minced Meat } \\
\text { (35 isolated strains) }\end{array}$ & $\begin{array}{l}\text { Raw Milk } \\
\text { (21isolated strains) }\end{array}$ & $\begin{array}{l}\text { Kareesh Cheese } \\
\text { (31 isolated strains) }\end{array}$ & $\begin{array}{l}\text { Diarrheal Stools } \\
\text { (28 isolated strains) }\end{array}$ & Total (115) \\
\hline \multirow[t]{4}{*}{$\overline{\mathrm{EPEC}}$} & O86:K61 (B7) & $2(5.71 \%)$ & & - & 年 & $10(8.7 \%)$ \\
\hline & O124:K72 & $2(5.71 \%)$ & $2(9.52 \%)$ & - & - & \\
\hline & O158:K- & $1(2.86 \%)$ & - & - & - & \\
\hline & O114:K90 & - & - & - & $3(10.71 \%)$ & \\
\hline \multirow[t]{2}{*}{ EHEC } & $\mathrm{O} 145: \mathrm{K}-$ & $1(2.86 \%)$ & - & $1(3.23 \%)$ & - & $8(6.95 \%)$ \\
\hline & $\mathrm{O} 26: \mathrm{K} 60$ & & $3(14.29 \%)$ & $3(9.67 \%)$ & - & \\
\hline \multirow[t]{3}{*}{ ETEC } & $\mathrm{O} 25: \mathrm{K} 11$ & $3(8.57 \%)$ & - & - & - & $5(4.35 \%)$ \\
\hline & O115:K-: & - & - & $1(3.23 \%)$ & - & \\
\hline & O8:K-: & - & - & $1(3.23 \%)$ & - & \\
\hline EAEC & O44:K74 & - & - & $3(9.67 \%)$ & - & $3(2.61 \%)$ \\
\hline EIEC & O124:K86 & - & - & - & $2(7.15 \%)$ & $2(1.74 \%)$ \\
\hline
\end{tabular}

Serological identification:

All E. coli isolates were subjected to serological identification using 9 polyvalent antisera then we applied monovalent antisera to positive reactions

Table 4. Percentage of antibiotic resistance of O-typable E. coli $(\mathrm{n}=28)$

\begin{tabular}{lccrr}
\hline Antimicrobial agent & Susceptible & Intermediate & Resistant & \% Resistance \\
\hline 1-Erythromycin & 1 & 7 & 20 & $71.5 \%$ \\
2-Cefatriaxone & 14 & 12 & 2 & $7.1 \%$ \\
3-Chloramphenicol & 26 & 1 & 1 & $3.5 \%$ \\
4-Sulphamethoxazole/Trimethoprim & 23 & 1 & 4 & $14.2 \%$ \\
5-Ciprofloxacin & 27 & 0 & 1 & $3.5 \%$ \\
6- Azithromycin & 25 & 1 & 2 & $7.1 \%$ \\
7- Amikacin & 28 & 0 & 0 & 0 \\
8- Streptomycin & 15 & 0 & 13 & $46.4 \%$ \\
\hline
\end{tabular}

Antimicrobial susceptibility test: (Disk diffusion method), according to CLSI standards (2011):

All 28 Identified serotypes were tested for antibiotic resistance (selected 8 antibiotics)

Table 5. Frequency percentages and antibiotic resistance of identified $E$. coli Serotypes $(\mathrm{n}=28)$

\begin{tabular}{lllll}
\hline SOURCE & Serotype & $\mathrm{N}^{\mathrm{O}}$ & $\mathbf{\%}$ & Resistant \\
\hline Cheese & O44:K74 & 3 & $10.7 \%$ & $\mathrm{E}, \mathrm{S}$ \\
& O26:K60 & 3 & $10.7 \%$ & $\mathrm{E}$ \\
& O145:K- & 1 & $3.6 \%$ & $\mathrm{E}$ \\
O115:K- & 1 & $3.6 \%$ & $\mathrm{~S}$ \\
Milk & O8:K- & 1 & $3.6 \%$ & $\mathrm{E}, \mathrm{S}$ \\
Minced meat & O26:K60 & 3 & $10.7 \%$ & $\mathrm{E}$ \\
& O124:K72 & 2 & $7.14 \%$ & $\mathrm{~S}$ \\
& O145:K- & 1 & $3.6 \%$ & - \\
& O158:K- & 1 & $3.6 \%$ & $\mathrm{E}, \mathrm{S}$ \\
O86:K61 & 2 & $7.14 \%$ & $\mathrm{E}, \mathrm{S}$ \\
O124:K72 & 2 & $7.14 \%$ & $\mathrm{E}, \mathrm{STX}, \mathrm{CIP}, \mathrm{S}$ \\
Total & O25:K11 & 3 & $10.7 \%$ & $\mathrm{E}, \mathrm{CRO}, \mathrm{STX}, \mathrm{AZM}$ \\
\hline
\end{tabular}

(E): Erythromycin; (CRO) Cefatriaxone; (C) Chloramphenicol; (CIP) Ciprofloxacin; (STX) Trimethoprim-Sulphamethoxazole; (AZM) Azithromycin (AK) Amikacin and (S) Streptomycin

Genotypic detection of E. coli:

Multiplex Polymerase Chain Reaction:

All 115 E. coli isolates were subjected for detection of $S t x_{1}, S t x_{2}$, eaeA and hlyA genes in a single reaction 


\begin{tabular}{|c|c|c|c|c|c|c|c|c|c|}
\hline \multirow[b]{2}{*}{ Sample } & \multirow[b]{2}{*}{ No. } & \multicolumn{2}{|c|}{ eae } & \multicolumn{2}{|l|}{$S t x_{1}$} & \multicolumn{2}{|l|}{$S t x_{2}$} & \multicolumn{2}{|c|}{ hlyA } \\
\hline & & No & $\%$ & No & $\%$ & No & $\%$ & No & $\%$ \\
\hline Meat & 35 & 3 & 8.5 & - & - & - & - & - & - \\
\hline Milk & 21 & 2 & 9.5 & 1 & 4.7 & - & - & - & - \\
\hline Cheese & 31 & 1 & 3.2 & - & - & 1 & 3.20 & - & - \\
\hline Stool & 28 & 2 & 7.1 & - & - & 1 & 3.60 & - & - \\
\hline Total & 115 & 8 & 7.0 & 1 & 0.87 & 2 & 1.74 & - & - \\
\hline
\end{tabular}

Table 3 results of antimicrobial susceptibility.

\section{Multiplex PCR}

The multiplex PCR detected targeted genes in 10 out of $115(8.7 \%)$ collected samples. Seven samples possessed eaeA gene alone (70\%); while 2 samples contained $S t x_{2}$ gene. Both $S t x 1$ and eaeA genes were detected in one sample.

Table 4 to 6 the illustrated results of multiplex PCR.

\section{Discussion}

E. coli, which are normal flora of the human and animal intestine, have been identified as a leading cause of food borne illness all over the world. E. coli strains have previously been isolated from meat samples and have also been implicated in the contamination of vegetables such as lettuce (Hilborn et al., 1999; Enabulele and Uraih, 2009). In our study, the incidence of $E$. coli was $35 \%$ in minced meat and $26 \%$ in raw milk and kareesh cheese. This was lower than that reported by other authors (Al-Gallasa et al., 2002; Hussein and Sakuma, 2005; Temelli et al., 2012); while it was higher than that reported by (Abdul-Raouf et al., 1996; Heuvelink et al., 1998; 1999; Dontorou et al., 2003). There are many factors affecting the differences in prevalence rates among studies; these differences are mainly related to samples and sampling (type, source/location and initial bacterial load), environmental and seasonal factors and the detection methodology used (Temelli et al., 2012). Usually high incidence is attributing to behavior of slaughtering and manipulation of food before reaching the market. Additionally, in this study E. coli incidence in diarrheal samples was $24.35 \%$ which almost the same reported in other studies (Nguyen et al., 2005; Bueris et al., 2007) and lower than that reported by (Keskimäki et al., 2000; Amisano et al., 2011). Regarding to Serotyping, the most identified isolates in our study were EHEC strains. Although E. coli $\mathrm{O} 157: \mathrm{H} 7$ was the most common EHEC strain in many regions of the world; serotypes O5, O26, O91, O103, O111, O113 and $\mathrm{O} 145$ were also recognized as a serious threat to public health and have been recovered from infected patients (Fagan et al., 1999; Perelle et al., 2007). Of the typeable E. coli isolates found, O26:K60 was the most common type with a percentage of 21.4 ( 6 isolates). Among the identified serotypes, O124:K72 was representing 14.3\% which was higher than that reported in Kalyobia governorate, Egypt (Hassanien, 2004). In addition O44:K74, O114:K90 and $\mathrm{O} 25: \mathrm{K} 11$ are also found in $10.7 \%$. In our study, no $E$. coli $\mathrm{O} 157: \mathrm{H} 7$ was isolated and that similar to that reported in other studies (Dontorou et al., 2003; Fantelli and Stephan, 2001).

Concerning the antibiotic susceptibility of the seroidentified strains. All strains were resistant to one or more tested antibiotics. This was similar to that conducted by (Radu et al., 2001). Twenty two out of 28 $(78.57 \%)$ were resistant to at least one antibiotic and 6 strains $(21.43 \%)$ were resistant to 3 or more antibiotics. These results show higher resistance profiles than that reported by (Dontorou et al., 2003). No antimicrobial resistance was observed against Amikacin (Aminoglycoside), while other studies showed resistance pattern that reach up to $10 \%$ (Rigobelo et al., 2010; Aly et al., 2012). Meanwhile resistance towards Erythromycin was $96.43 \%$; which higher than that reported in other studies (Harakeha et al., 2005). This high percentage of Erythromycin resistance refers to its frequent use in our country. Such resistance may not only be a direct concern to human health, but also, it is important because it could be transferred to other important pathogenic serotypes (Dzidic and Bedeković, 2003).

By using the multiplex PCR for the detection of $S t x_{1}$, $S t x_{2}$, eaeA and EHEC hlyA virulence genes out of 115 isolates which were identifies as $E$. coli by biochemical tests, 10 samples showed positive results for the target genes. In the present study, eaeA positive $E$. coli isolates that were negative for other virulence genes were found to be predominant $(70 \%)$. This result was higher than that reported in other studies (Dhanashree and Mallya, 2008; Sharifi-Yazdi, 2011). EHEC hlyA gene was not found in any of examined isolates; which contrary to what found in other studies (Paton and Paton, 1998; Dastmalchi and Ayremlou, 2012). Two isolates (20\%) carried $S_{t} x_{2}$ gene which lower than that reported by Sharifi-Yazdi et al. (2011; Dastmalchi and Ayremlou, 2012). One isolate only (10\%) showed association between $s t x_{1}$ and eaeA genes.

\section{Conclusion}

This study revealed that minced meat, raw milk and kareesh cheese were contaminated by $E$. coli and represented a public health hazard, therefore measures 
should be taken to avoid such contamination and the product should be heat treated during manufacturing or before consuming. There is an increasing demand for improved diagnostic procedures for the detection of Shiga Toxigenic Escherichia Coli (STEC) in fecal samples and, in foods of animal origin because their ability to cause life-threatening diseases. However, considering the difficulty of performing phenotypic assay in some laboratories, the multiplex PCR can be used as a replacement of such conventional methods in detection of E. coli strains particularly the emerging ones.

\section{Author's Contributions}

All authors equally contributed in this work.

\section{Ethics}

This article is original and contains unpublished material. The corresponding author confirms that all of the other authors have read and approved the manuscript and no ethical issues involved.

\section{References}

Abdul-Raouf, U.M., M.S. Ammar and L.R. Beuchat. 1996. Isolation of Escherichia coli O157: H7 from some Egyptian foods. Int. J. Food Microbiol., 29: 423-426. DOI: 10.1016/0168-1605(95)00076-3

Al-Gallasa, N., R. Ben Aissa Ra, T. Attia Annabib, O. Bahric and A. Boudabousd, 2002. Isolation and characterization of shiga toxin-producing Escherichia coli from meat and dairy products. Food Microbiol., 19: 389-398.

DOI: 10.1006/fmic.2002.0488

Aly, M.E.A., T.M. Essam and M.A. Amin, 2012. Antibiotic resistance profile of $E$. coli strains isolated from clinical specimens and food samples in Egypt. Intl. J. Microbiol. Res., 3: 176-182.

Amisano, G., S. Fornasero, G. Migliaretti, S. Caramello and V. Tarasco et al., 2011. Diarrheagenic Escherichia coli in acute gastroenteritis in infants in North-West Italy. New Microbiol., 34: 45-51. PMID: 21344146

Arif, S.K. and L.I.F. Salih, 2010. Identification of different categories of diarrheagenic Escherichia coli in stool samples by using multiplex PCR technique. Asian J. Med. Sci., 2: 237-243.

Bueris, V., M.P. Sircili, C.R. Taddei, M.F. Dos Santos and M.R. Franzolin et al., 2007. Detection of diarrheagenic Escherichia coli from children with and without diarrhea in Salvador, Bahia, Brazil. Mem. Inst. Oswaldo Cruz., 102: 839-844. PMID: 17992362

CLSI, 2011. Performance standards for antimicrobial susceptibility testing. Clinical and Laboratory Standards Institute, Pennsylvania: Wayne.
Conedera, G., E. Mattiazzi, F. Russo, E. Chiesa and I. Scorzato et al., 2007. A family outbreak of Escherichia coli $\mathrm{O} 157$ haemorrhagic colitis caused by pork meat salami. Epidemiol. Infect., 135: 311-314. DOI: $10.1017 / \mathrm{S} 0950268806006807$

Dastmalchi, S.H. and N. Ayremlou, 2012. Characterization of Shiga Toxin-Producing Escherichia Coli (STEC) in feces of healthy and diarrheic calves in Urmia region, Iran. Iran J. Microbiol., 4: 63-69. PMID: 22973471

De Boer, E. and A.E. Heuvelink, 2000. Methods for the detection and isolation of Shiga toxin-producing Escherichia coli. J. Appl. Microbiol., 88: 133S-143S. DOI: $10.1111 /$ j.1365-2672.2000.tb05341.x

Dhanashree, B. and P.S. Mallya, 2008. Detection of Shiga-Toxigenic Escherichia Coli (STEC) in diarrhoeagenic stool and meat samples in Mangalore, India. Indian J. Med. Res., 128: 271-277.

Dontorou, C., C. Papadopoulou, G. Filioussis, V. Economou and I. Apostolou et al., 2003. Isolation of Escherichia coli O157:H7 from foods in Greece. Int. J. Food Microbiol., 82: 273-279. DOI: 10.1016/S0168-1605(02)00313-6

Dzidic, S. and V. Bedeković, 2003. Horizontal gene transfer-emerging multidrug resistance in hospital bacteria. Acta Pharmacol. Sin., 24: 519-526. PMID: 12791177

Enabulele, S.A. and N. Uraih, 2009. Enterohaemorrhagic Escherichia coli 0157:H7 Prevalence in meat and vegetables sold in Benin City, Nigeria. Afr. J. Microbiol. Res., 3: 276-279.

Fagan, P.K., M.A. Hornitzky, K.A. Bettelheim and S.P. Djordjevic, 1999. Detection of Shiga-Like Toxin $\left(S_{t} x_{1}\right.$ and Stx $)$, Intimin (eaeA) and Enterohemorrhagic Escherichia coli (EHEC) Hemolysin (EHEC hlyA) Genes in Animal Feces by Multiplex PCR. Applied Environ. Microbiol., 65: 868-872.

Fantelli, K. and R. Stephan, 2001. Prevalence and characteristics of shigatoxin-producing Escherichia coli and Listeria monocytogenes strains isolated from minced meat in Switzerland. Int. J. Food Microbiol., 70: 63-69. PMID: 11759763

Farmer, J.J., B.R. Davis, F.W. Hickman-Brenner, A. McWhorter and G.P. Huntleycarter et al., 1985. Biochemical identification of new species and biogroups of Enterobacteriaceae isolated from clinical specimens. J. Clin. Microbiol., 21: 46-76. PMID: 3881471

Harakeha, S., H. Yassinea, M. Ghariosb, E. Barbourc and S. Hajjara et al., 2005. Isolation, molecular characterization and antimicrobial resistance patterns of Salmonella and Escherichia coli isolates from meat-based fast food in Lebanon. Sci. Total Environ., 341: 33-44.

DOI: $10.1016 /$ j.scitotenv.2004.09.025 
Hassanien, F.S., 2004. Bacterial hazards associated with consumption of some meat products. Benha Vet. Med. J., 15: 41-54.

Heuvelink, A.E., F.L.A.M. Van Den Biggelaar, J.T.M. Zwartkruis-Nahuis, R.G. Herbes and R. Huyben et al., 1998. Occurrence of Verocytotoxin-Producing Escherichia coli $\mathrm{O} 157$ on Dutch Dairy Farms. J. Clin. Microbiol., 36: 3480-3487.

Heuvelink, A.E., J.T. Zwartkruis-Nahuis, R.R. Beumer and E. De Boer, 1999. Occurrence and survival of verocytotoxin-producing Escherichia coli O157 in meats obtained from retail outlets in The Netherlands. J. Food Prot., 62: 1115-1122. PMID: 10528713

Hilborn, E.D., J.H. Mermin, P.A. Mshar, J.L. Hadler and A. Voetsch et al., 1999. A multistate outbreak of Escherichia coli $\mathrm{O} 157: \mathrm{H} 7$ infections associated with consumption of mesclun lettuce. Arch. Intern. Med., 159: 1758-1764. DOI: 10.1001/archinte.159.15.1758

Hussein, H.S. and T. Sakuma, 2005. Invited review: Prevalence of Shiga toxin-producing Escherichia coli in dairy cattle and their products. J. Dairy Sci., 88: 450-465. DOI: $10.3168 /$ jds.S0022-0302(05)72706-5

Keskimäki, M., L. Mattila, H. Peltola and A. Siitonen, 2000. Prevalence of diarrheagenic escherichia coli in finns with or without diarrhea during a round-theworld trip. J. Clin. Microbiol., 38: 4425-4429. PMID: 11101575

Nataro, J.P. and J.B. Kaper, 1998. Diarrheagenic Escherichia coli. Clin. Microbiol. Rev., 11: 142-201. PMID: 9457432

Nguyen, T.V., P. Le Van, C. Le Huy, K.N. Gia and A. Weintraub, 2005. Detection and Characterization of Diarrheagenic Escherichia coli from Young Children in Hanoi, Vietnam. J. Clin. Microbiol., 43: 755-760. PMID: 15695676.

Paton, A.W. and J.C. Paton, 1998. Detection and characterization of Shiga toxigenic Escherichia coli by using multiplex PCR assays for $S t x_{1}, S t x_{2}$, eaeA, enterohemorrhagic $E$. coli hlyA, rfbO111 and rfbO157. J. Clin. Microbiol., 36: 598-602. PMID: 9466788
Perelle, S., F. Dilasser, J. Grout and P. Fach, 2007. Screening food raw materials for the presence of the world's most frequent clinical cases of Shiga toxinencoding Escherichia coli O26, O103, O111, O145 and O157. Int. J. Food Microbiol., 113: 284-288. DOI: 17134783.

Qadri, F., A.M. Svennerholm, A.S. Faruque and R.B. Sack, 2005. Enterotoxigenic Escherichia coli in developing countries: Epidemiology, microbiology, clinical features, treatment and prevention. Clin. Microbiol. Rev., 18: 465-483. PMID: 16020685

Radu, S., O.W. Ling, G. Rusul, M.I. Karim and M. Nishibuchi, 2001. Detection of Escherichia coli O157:H7 by multiplex PCR and their characterization by plasmid profiling, antimicrobial resistance, RAPD and PFGE analyses. J. Microbiol. Methods, 46: 131-139. DOI: 10.1016/S0167-7012(01)00269-X

Rigobelo, E.C., R.P. Maluta and F.A. De Avila, 2010. Antimicrobial susceptibility pattern of shiga toxinproducing Escherichia coli strains. J. Microbiol. Antimicrob., 2: 113-117.

Sharifi-Yazdi, M.K., A. Akbari and M.M. Soltan Dallal, 2011. Multiplex Polymerase Chain Reaction (PCR) assay for simultaneous detection of Shiga-like toxin $\left(S t x_{1}\right.$ and $\left.S t x_{2}\right)$, intimin (eae) and invasive plasmid antigen $\mathrm{H}$ (ipaH) genes in diarrheagenic Escherichia coli. Afr. J. Biotechnol., 10: 1522-1526.

Stenutz, R., A. Weintraub and G. Widmalm, 2006. The structures of Escherichia coli O-polysaccharide antigens. FEMS Microbiol. Rev., 30: 382-403. PMID: 16594963

Temelli, S., A. Eyigor and S. Anar, 2012. Prevalence of Escherichia coli $\mathrm{O} 157$ in red meat and meat products determined by VIDAS ECPT and light cycler PCR. Turk J. Vet. Anim. Sci., 36: 305-310.

Toma, C., Y. Lu, N. Higa, N. Nakasone and I. Chinen et al., 2003. Multiplex PCR assay for identification of human diarrheagenic Escherichia coli. J. Clin. Microbiol., 41: 2669-2671. PMID: 12791900

Yokoyama, T., 1993. Study on mec gene in methicillinresistant staphylococci. Kansenshogaku Zasshi., 67: 1203-1210. PMID: 8294771 